\title{
Screening of Potassium Releasing Rhizospheric Isolates for Agrochemicals Compatibility
}

\author{
Y. Nagaraju ${ }^{1 *}$, S. Triveni ${ }^{1}$, R. Subhash Reddy ${ }^{1}$ and B. Vidyasagar ${ }^{2}$ \\ ${ }^{1}$ Department of Agricultural Microbiology, PJTSAU, Rajendranagar, \\ Hyderabad-30, Telangana, India \\ ${ }^{2}$ Department of Plant Pathology, PJTSAU, Rajendranagar, Hyderabad-30, Telangana, India \\ *Corresponding author
}

\section{A B S T R A C T}

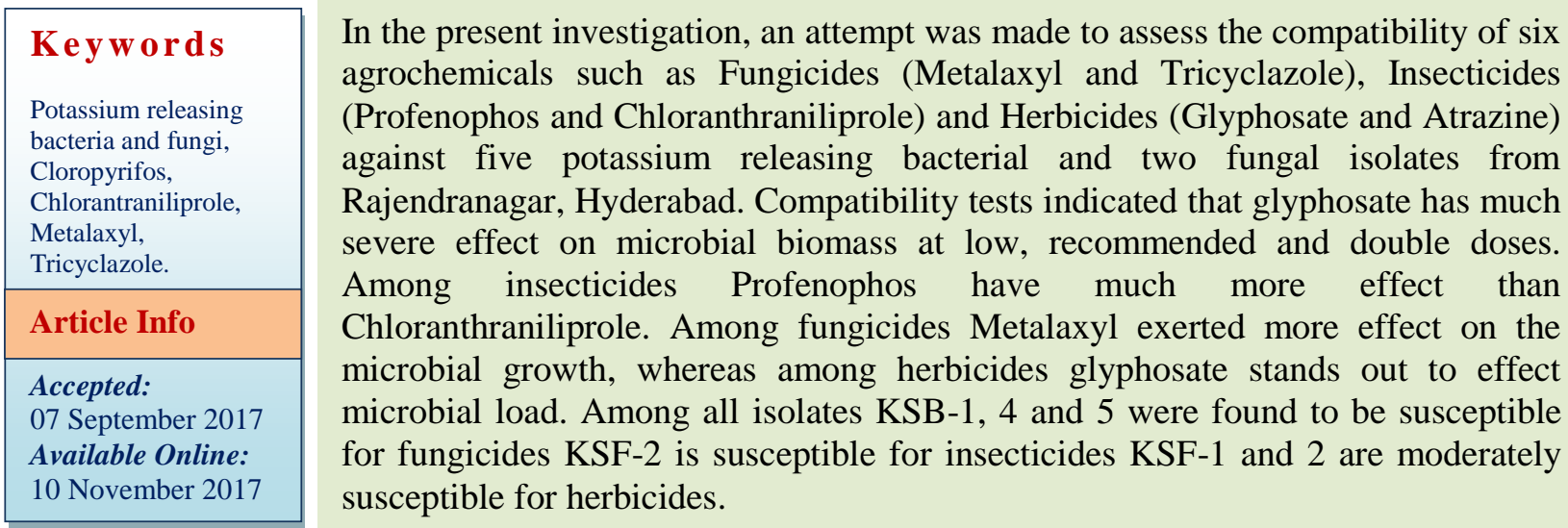

\section{Introduction}

Pesticides are the important agrochemicals used for prevention of crops from pests. Their use has been hiked during last few decades. The indiscriminate use of pesticides disturbs the soil environment by affecting flora and fauna including microflora of soil, and also the physicochemical properties of soil like $\mathrm{pH}$, salinity, alkalinity leading to infertility of soil (Sarnaik et al., 2006). The production of pesticides started in India in 1952 with the establishment of a plant for the production of BHC near Calcutta, and India is now the second largest manufacturer of pesticides in Asia after China and ranks twelfth globally
(Mathur, 1999). Pesticide application is still the most effective and accepted means for the protection of plants from pest (Bolognesi, 2003). But the extensive use of pesticides over the past four decades has resulted in tribulations caused by the interaction with natural biological system (Ayansina and Oso, 2006). Application of fungicides may harmfully effect the non-target soil microflora (Ayansina and Oso, 2006), especially when these fungicides are used in conjunction with microbial inoculants they cause damage to the inoculants by affecting the bacterial infection to the root hair, nodule formation and 
bacterial growth hormone production. This important issue attracted a negligible amount of research in the past and not much more in recent years. The majority of work has been done under in vitro conditions (Ingham and Coleman, 1984; Bashan and Holguin, 1997) for leguminous crops on the basis of biochemical (Revellin et al., 1993), as well as molecular technologies (Sigler, 1999; Sigler and Turco, 2002; Crecchio et al., 2001). Ensuring food quality, human health and environmental protection are key considerations to develop the compatibility studies between chemical and biological pesticides. Compatible phytosanitary products are useful for the sustainable pest and disease management. Control of plant diseases by the use of antagonistic microorganisms can be an effective means (Cook and Baker, 1983). Weeds and pests are known to affect the agricultural crops and cause yield reduction (Kortekamp, 2011). This agronomic situation demand for herbicides application to reduce or to some extent eliminates weeds for high crop yield performance. However, between and within the soil medium, are groups of biota such as bacteria, fungi, nematodes, earthworms, termites and protozoa, which may be affected by this application (FAO, 2006).While, the vital roles played by these complex organisms in soil medium have been described as residue decomposition, nutrient recycling, soil structural stability and degradation of soil pollutants (Usman, 2016; Barman, 2008). This entails the need to understand the effect as well as the relationship between soil biota and pesticide chemicals.

The present study was designed to evaluate the adverse effect of Agrochemicals, on growth, survival of potassium releasing microorganisms under laboratory conditions using various toxicity experiments. This leads to reducing potassium releasing microorganisms count in soil rhizosphere. The main aim of this study was to screen out pesticides tolerant strains of Potassium Releasing Microorganisms for the improvement of biofertilizer for sustainable agriculture.

\section{Materials and Methods}

\section{Collection and processing of rhizosphere soil}

Rhizosphere soils of different crops like Green gram, Soybean, Maize, Rice, Cotton and Sorghum were collected from a depth of $0-15 \mathrm{~cm}$. Soil samples were collected from college farm and student farm at College of Agriculture, Rajendranagar, Hyderabad. Soils were shade dried for $24 \mathrm{hr}$ and removed coarse and unwanted plant debris.

\section{Isolation of potassium releasing rhizospheric microorganisms}

The potassium releasing bacteria was isolated from the rhizosphere soil by serial dilution plate method using modified Aleksandrov's medium containing $0.2 \%$ insoluble mica powder or potassium alumino silicate as insoluble potassium source. The serial dilutions of the soil samples were made up to $10^{-5}$ and $0.1 \mathrm{ml}$ of diluted soil suspension was plated on Aleksandrov medium plates (Prajapati and Modi, 2012). The plates were incubated at $28 \pm 2{ }^{\circ} \mathrm{C}$ in biological oxygen demand (BOD) incubator for 3-4 days. Detection of potassium solubilization by different rhizobacterial isolates were based upon the ability of solubilization zone formation. The rhizobacterial isolates were maintained by transfer on Aleksandrov agar medium slants.

\section{Screening for compatibility of Potassium releasing microorganisms with agrochemicals}

Compatibility of bacterial test isolates with commonly used agrochemicals like 
Fungicides(Metalaxyl and Tricyclazole), Insecticides (Profenofos and Chlorantraniliprole) and Herbicides (Atrazine and Glyphosate) (Table 1) were tested by following inhibition zone technique at recommended, half recommended and double the recommonded dosages by maintaining three replications (Mohiddin and Khan, 2013).

The following fungicides, insecticides, and herbicides were evaluated against zinc solubilizers under in vitro conditions by poisoned food technique method.

Evaluation of effect of Fungicides, Insecticides and Herbicides on rhizospheric isolates under laboratory conditions

Efficacy of two fungicides, two insecticides and two herbicides (Table 1) were tested against rhizospheric bacteria and fungi under in vitro conditions by poisoned food technique at three concentrations, i.e., half, recommended and double doses. For each treatment, $100 \mathrm{ml}$ of nutrient agar/potato dextrose medium was taken in $250 \mathrm{ml}$ conical flask and sterilized in an autoclave. To the sterilized medium, fungicide/insecticide/herbicide was added at lukewarm temperature and mixed thoroughly by shaking to obtain required concentrations. The poisoned medium was equally distributed in the Petri plates and allowed to solidify (Nene and Thapliyal, 1993).

Three replications were maintained for each treatment whereas, for fungal cultures evaluation, Discs $(5 \mathrm{~mm})$ of actively growing test fungal cultures were cut with sterilized cork borer and transferred to the center of the poisoned medium in each of the Petri plates. Similarly, control was maintained by placing $5 \mathrm{~mm}$ discs of test fungal culture in center of the plates containing the medium without fungicide. For bacterial isolates a volume of
$0.1 \mathrm{ml}$ containing $10^{7}$ cells $\mathrm{ml}^{-1}$ was taken with help of micropipette and transferred on to the poisoned medium. The transferred medium was spreaded equally with help of sterile spreaders. All the Petri plates were incubated at $28 \pm 2{ }^{\circ} \mathrm{C}$ in BOD incubator. The bacterial count will be taken after 2 - 4 days of incubation.

For fungal isolates the diameter of fungal colony was measured in each of the treatment when the fungal colony growth in control plate was full. The colony diameter inhibited in fungicide treated plates as compared to control was taken as a measure of fungi toxicity. Per cent inhibition over control was calculated by following the equation:

$I=\frac{\mathrm{C}-\mathrm{T}}{\mathrm{C}}$

Where,

$\mathrm{I}=$ Per cent inhibition of mycelial growth

$\mathrm{C}=$ Radial growth of pathogen in control $(\mathrm{mm})$

$\mathrm{T}=$ Radial growth of pathogen in treatment (mm)

\section{Results and Discussion}

\section{Effect of Fungicides on potassium releasing isolates}

The isolates were screened for their compatibility with the two commonly used Fungicides (Metalaxyl and Tricyclazole). Among five bacterial and two fungal isolatesKSB-2, KSF-1 and KSF-1 exhibited good compatibility (0 $\mathrm{mm}$ inhibition) with fungicide Metalaxyl at low dosages (Table 2). Similarly with Tricyclazole KSB-1, 2 and KSF-2 exhibited compatibility at low doses. 
Recommended and double doses considerably inhibited the growth of bacteria and fungi. Sharvani (2011) reported similar results with the Pseudomonas, Bacillus, Rhizobium compatibility studies against commonly used agrochemicals like Fungicides (Copper oxy chloride, Carbendazim, Thiram and Captan) Insecticides (Phorate, Carbofuran, Imidachloprid and Chlorpyriphos) and Herbicides (Alachlor, Butachlor, Pendimethalin and Oxyfluorofen) at their recommended and half recommended dosages. Similar results was found by Neeraja et al., (2014) who studied Carbendazim (0.2\%), Chlorpyriphos (0.25\%), Pendimethalin $(0.66 \%)$ and zinc sulphate $(0.2 \%)$ under pot culture experiment by using chickpea. Ahmed et al., (2007) reported the effect of different concentrations $(0,10,20$, $50,100,200,500$ and $1000 \mu \mathrm{g} \mathrm{L}^{-1}$ ) of the fungicides Captan, Thiram, Luxan, Fernasan$\mathrm{D}$ and Milcurb on inhibition of growth and colony sizes of seven Rhizobium strains. All strains were tolerant to low fungicide concentrations but they were sensitive to high concentrations.

Effect of insecticides on potassium releasing isolates

All the isolates were screened for their compatibility with the two commonly used insecticides (Chlorantraniliprole and Profenophos). Isolates were not affected by any insecticides at recommended and low doses, whereas at double dose of Profenophos all the isolates were susceptible. Chlorantraniliprole have effect on the growth of fungal isolates at higher doses. Pesticide soil treatment did not affect the abundance of culturable phosphate solubilizing bacteria Maria et al., (2015). Chennappa et al., (2014) found that Pendimethalin, Chloropyrifos, Glyphosate and Phorate effect nitrogen fixation, indole acetic acid, gibberellic acid, and phosphate solubilizationat low concentration.

Table.1 Details of the fungicides, insecticides and herbicides used in bioassay studies under in vitro condition

\begin{tabular}{|c|c|c|c|c|c|c|}
\hline $\begin{array}{l}\text { S. } \\
\text { No. }\end{array}$ & Fungicides & $\begin{array}{l}\text { Recommended } \\
\text { Dosages (ppm) }\end{array}$ & Insecticides & $\begin{array}{l}\text { Recommended } \\
\text { dosages (ppm) }\end{array}$ & Herbicides & $\begin{array}{l}\text { Recommended } \\
\text { dosages (ppm) }\end{array}$ \\
\hline 1. & Metalaxyl & 200 & Profenophos & 200 & Atrazine & 2000 \\
\hline 2. & Tricyclazo-le & 60 & Chlorantra-niliprole & 40 & Glyphosate & 1000 \\
\hline 3. & \multicolumn{2}{|c|}{ Control (Without fungicide) } & & & & \\
\hline
\end{tabular}

Table.2 Compatibility study of potassium releasing isolates with fungicides

\begin{tabular}{|c|c|c|c|c|c|c|}
\hline \multirow{3}{*}{ Isolates } & \multicolumn{6}{|c|}{ Fungicides } \\
\hline & \multicolumn{3}{|c|}{ Metalaxyl } & \multicolumn{3}{|c|}{ Tricyclazole } \\
\hline & Low & Normal & Double & Low & Normal & Double \\
\hline KSB-1 & $\mathrm{L}$ & $\mathrm{L}$ & $\mathrm{L}$ & $\mathrm{H}$ & MD & $\mathrm{L}$ \\
\hline KSB-2 & $\mathrm{H}$ & MD & $\mathrm{L}$ & $\mathrm{H}$ & MD & $\mathrm{L}$ \\
\hline KSB-3 & $\mathrm{MD}$ & $\mathrm{L}$ & $\mathrm{L}$ & $\mathrm{L}$ & $\mathrm{L}$ & $\mathrm{L}$ \\
\hline KSB-4 & $\mathrm{L}$ & $\mathrm{L}$ & $\mathrm{L}$ & $\mathrm{L}$ & $\mathrm{L}$ & $\mathrm{L}$ \\
\hline KSB-5 & $\mathrm{L}$ & $\mathrm{L}$ & $\mathrm{L}$ & $\mathrm{L}$ & $\mathrm{L}$ & $\mathrm{L}$ \\
\hline KSF-1 & $\mathrm{H}$ & MD & $\mathrm{L}$ & $\mathrm{L}$ & $\mathrm{L}$ & $\mathrm{L}$ \\
\hline KSF-2 & $\mathrm{H}$ & MD & $\mathrm{L}$ & $\mathrm{H}$ & MD & $\mathrm{L}$ \\
\hline
\end{tabular}

H - Highly compatible, MD - Moderately compatible, L - Less compatible 
Table.3 Effect of different insecticides on potassium releasing microorganisms

\begin{tabular}{|l|c|c|c|c|c|c|}
\hline & \multicolumn{9}{c}{ Isolates } & \multicolumn{2}{c}{ Insecticides } \\
\hline & Low & Normal & Double & Low & Normal & Double \\
\hline KSB-1 & H & MD & L & H & H & H \\
\hline KSB-2 & H & H & L & H & H & H \\
\hline KSB-3 & H & H & L & H & H & H \\
\hline KSB-4 & MD & MD & L & H & H & H \\
\hline KSB-5 & MD & MD & L & H & H & H \\
\hline KSF-1 & MD & MD & L & H & H & L \\
\hline KSF-2 & H & MD & L & MD & L & L \\
\hline
\end{tabular}

H- Highly compatible, MD- Moderately compatible, L- Less compatible

Table.4 Effect of herbicides on potassium releasing microorganisms

\begin{tabular}{|c|c|c|c|c|c|c|}
\hline \multirow[t]{3}{*}{ Isolates } & \multicolumn{6}{|c|}{ Herbicides } \\
\hline & \multicolumn{3}{|c|}{ Atrazine } & \multicolumn{3}{|c|}{ Glyphosate } \\
\hline & Low & Normal & Double & Low & Normal & Double \\
\hline KSB-1 & $\mathrm{H}$ & $\mathrm{H}$ & $\mathrm{L}$ & $\mathrm{L}$ & $\mathrm{L}$ & $\mathrm{L}$ \\
\hline KSB-2 & $\mathrm{H}$ & $\mathrm{H}$ & $\mathrm{H}$ & $\mathrm{L}$ & $\mathrm{L}$ & $\mathrm{L}$ \\
\hline KSB-3 & $\mathrm{H}$ & $\mathrm{L}$ & $\mathrm{L}$ & $\mathrm{L}$ & $\mathrm{L}$ & $\mathrm{L}$ \\
\hline KSB-4 & $\mathrm{H}$ & $\mathrm{H}$ & $\mathrm{L}$ & $\mathrm{L}$ & $\mathrm{L}$ & $\mathrm{L}$ \\
\hline KSB-5 & $\mathrm{H}$ & $\mathrm{H}$ & $\mathrm{L}$ & $\mathrm{L}$ & $\mathrm{L}$ & $\mathrm{L}$ \\
\hline KSF-1 & $\mathrm{H}$ & $\mathrm{L}$ & $\mathrm{L}$ & MD & MD & $\mathrm{L}$ \\
\hline KSF-2 & $\mathrm{H}$ & $\mathrm{L}$ & $\mathrm{L}$ & $\mathrm{H}$ & MD & $\mathrm{L}$ \\
\hline
\end{tabular}

H- Highly compatible MD- Moderately compatible L- Less compatible

Sayali et al., (2012) found that the transformed strain acquired the ability to grow in presence of higher concentrations of pesticides. Aditi and Raut (2011) screened pesticide resistant isolates of plant growth promoting microorganisms. Vimal and Patel (2011) reported that pesticides viz., Carbendazim, Monocrotophos and Chlorpyriphos increased the phosphate solubilizing activity of Bacillus sphaericus and Burkholderia cepacia at their recommended dose (Table 3 ).

\section{Effect of herbicides on potassium releasing isolates}

All the isolates were evaluated for their compatibility with the two commonly used herbicides (Atrazine and Glyphosate). Some isolates showed high compatibility $(0 \mathrm{~mm}$ inhibition zone) with atrazine except KSB-3, KSF-1 and KSF-2 i.e., they were less compatible with atrazine. Isolates KSF-1 and KSF-2 were moderately affected by Glyphosate herbicide at normal recommended doses (Table 4). Glyphosate has severe effect on the growth of bacteria at all the doses whereas fungi somehow managed to grow at low and recommended doses.

Similar results were reported by Ebtesam et al., (2013) who isolated Atrazine-resistant soil bacteria from different contaminated soils. Maheswari (2013) found that Pseudomonas isolates with systemic and nonsystemic fungicides. Madhaiyan et al., (2006) reported that insecticides Monocrotophos, Lindane and Dichlorvos had the most lethal action against 
Gluconacetobacter grown on LGIP medium, while Endosulphan, Chlorpyriphos, and Malathion effects were intermediate. Herbicides generally appeared to have no adverse effect on the growth and survival of Gluconacetobacter in the medium except for the concentrations exceeding recommended rates.

Pesticides are often considered a quick, easy, and inexpensive solution for controlling weeds and insect pests in urban landscapes. However, pesticide use comes at a significant cost. Pesticides have contaminated almost every part of our environment. Pesticide residues are found in soil and air, and in surface and ground water across the countries, and urban pesticide uses contribute to the problem. Pesticide contamination poses significant risks to the environment and nontarget organisms ranging from beneficial soil microorganisms, to insects, plants, fish, and birds. Contrary to common misconceptions, even herbicides can cause harm to the environment. In fact, weed killers can be especially problematic because they are used in relatively large volumes. The best way to reduce pesticide contamination (and the harm it causes) in our environment is for all of us to do our part to use safer, non-chemical pest control (including weed control) methods. The data on environmental-cum-health risk assessment studies may be regarded as an aid towards a better understanding of the problem. From the present study we revealed that herbicides have much impact than any other chemicals, reduced application or avoidance of application of these will conserve the nature for future.

\section{References}

Ahmed, T.H.M., Elsheikh, E.A.E and Mahdi, A.A. 2007. The in vitro compatibility of some Rhizobium and Bradyrhizobium strains with fungicides. African Crop Science Conference Proceedings. 8: 1171-
1178.

Ayansina, A.D.V and Oso, B.A. 2006. Effect of two commonly used herbicides on soil microflora at two different concentrations. African J. Biotech. 5(2): 129-132.

Barman, K.K and Varshney, J.G. 2008. Impact of herbicides on soil environment. Indian Journal of Weed Science 40: 10-17.

Bashan, Y and G. Holguin. 1997. Azospirillumplant relationship: Environmental and physiological advances (1990-1996). Can. J. Microbiol. 43: 103-121.

Bolognesi, C. 2003. Genotoxicity of pesticides: a review of human biomonitoring studies. Mutation Res. 543: 251-272.

Chennappa, G., Adkar, P.C.R., Naik, M.K., Suraj, U and Sreenivasa M.Y. 2014. Impact of pesticides on PGPR activity of Azotobacter $s p p$. isolated from pesticide flooded paddy soils. Greener Journal of Agricultural Sciences. 4 (4): 117-129.

Cook, R.J and Baker, K.F. 1983. The Nature and Practice of Biological Control of Plant Pathogens. American Phytopathological Society, St. Paul, MN.

Crecchio, C., Curci, M., Pizzigallo, M.D.R., Ricciuti, P and Ruggiero, P. 2001. Molecular approaches to investigate herbicide induced bacterial community changes in soil microcosms. Biol. Fertil. Soils, 33: 460-466.

Ebtesam, E.B., Sabir, J., Mansy, A.H and Zabermawi, N. 2013. Isolation, identification and acclimatization of Atrazine-resistant soil bacteria. Annals of Agricultural Science. 58 (2): 119-130.

FAO. 2005. The importance of soil organic matter: Key to drought resistant soil and sustained food production. FAO Soils Bulletin, No. 80.Food and Agricultural Organization of United Nation, Rome, Italy.65:11-47.

Ingham, E.R. and Coleman, D.C. 1984. Effects of streptomycin, cycloheximide, fungizone, captan, carbofuran, cygon, and PCNB on soil microorganisms. Microbial Ecology. 10(4): 345-358.

Kortekamp, A. 2011. Herbicides and environment. Publish InTech.

Madhaiyan, M., Poonguzhali, S., Hari, K., Saravanan, V.S and Tongmin, S. 2006. 
Influence of pesticides on the growth rate and plant-growth promoting traits of Gluconacetobacter diazotrophicus. Pesticide Biochemistry and Physiology. 84: 143-154.

Maheshwari, M.N. 2013. Compatibility of fluorescent Pseudomonads isolates with fungicides. International Journal of Food, Agriculture and Veterinary Sciences. 3 (2): 46-50.

Maria, S.A., Ornella, F., Jorge, G.A., Liliana, M.L., Fernando, I., Adriana, $\mathrm{F}$ and Tania, T. 2015. Effect of pesticides application on peanut (Arachis hypogaea L.) associated phosphate solubilizing soil bacteria. Applied Soil Ecology. 95: 31-37.

Mathur, S.C. 1999. Future of Indian pesticides industry in next millennium. Pesticide Information 24(4): 9-23.

Mohiddin, F. A and Khan, M. R. 2013. Tolerance of fungal and bacterial biocontrol agents to six pesticides commonly used in the control of soil borne plant pathogens. African Journal of Agricultural Research., 8(43): 5331-5334.

Neeraja, B., Manoj, K.V., Krishna, P.J and Anil, K.P. 2014. Effect of Agrochemicals on Trichoderma harzianum (Th4 Isolate) and its biocontrol potential against chickpea collar rot caused by Sclerotium rolfsii. International Journal of Food, Agriculture and Veterinary Sciences. 4 (3): 133-138.

Nene, Y.L and Thapliyal, P.N. 1993. Fungicides in plant disease control, 3rd Edition, Oxford and IBH publishing company, New Delhi.

Prajapati, K.B and Modi, H.A. 2012. Isolation and characterization of potassium solubilizing bacteria from ceramic industry soil. CIBTech Journal of Microbiology. 1 (2-3): 8-14.
Revellin, C., Leterme, P and Catroux, G. 1993. Effect of some fungicide seed treatments on the survival of Bradyrhizobium japonicum and on the nodulation and yield of soybean [Glycine max. (L) Merr.]. Bio. Fertil. Soils. 16: 211-214.

Sarnaik, S.S., Kanekar, P.P., Raut, V.M., Taware, S.P., Chavan, K.S and Bhadbhade, B.J. 2006. Effect of application of different pesticides to soybean on the soil microflora. Journal of Environmental Biology. 27(2): 423-426.

Sayali, R.N., Annika, A.D., Meeta, B., Jossy, V and Naresh, C. 2012. Isolation, characterization and identification of pesticide tolerating bacteria from garden soil. European Journal of Experimental Biology. 2 (5): 1943-1951.

Sigler, V. 1999. Detecting the effects of fungicides on soil bacterial populations using Denaturing Gradient Gel Electrophoresis (DGGE). www.agry. purdue.edu/ turf/report/1998/bacteria.pdf.

Sigler, V.W and Turco, R.F. 2002. The impact of Chlorothalonil application on soil bacterial and fungal populations as assessed by denaturing gradient gel electrophoresis. Appl. Soil Ecol. 21:107-118.

Usman, S., Muhammad, Y and Chiroman, A.M. 2016. Roles of soil biota and biodiversity in soil environment-A concise communication. Eurasian JSoil Sci. 5: 255265.

Vimal, R and Patel, H.H. 2011. Phosphate solubilization by Bacillus sphaericus and Burkholderia cepacia in presence of pesticides. Journal of Agricultural Technology. 7 (5): 1331-1337.

\section{How to cite this article:}

Nagaraju, Y., S. Triveni, R. Subhash Reddy and Vidyasagar, B. 2017. Screening of Potassium Releasing Rhizospheric Isolates for Agrochemicals Compatibility. Int.J.Curr.Microbiol.App.Sci. 6(11): 372-378. doi: https://doi.org/10.20546/ijcmas.2017.611.042 